\title{
A LATE-MEDIEVAL MANOR FARM IN ROVNÝ (ROKYCANY DISTRICT, PILSEN REGION)
}

\author{
DAVID NOVÁK - PAVEL VAŘEKA
}

\begin{abstract}
Several seasons of research centred on the features within a presumed manor farm in the deserted Medieval and Early Modern village of Rovný (Drahoňưv Újezd cadastral zone). This article sums up the preliminary outcomes of the research predominantly focused on a two-compartment house and a large cellar. The research was based on archaeological excavations as well as on the application of methods derived from natural sciences (geophysics, analyses of soils, analysis of macroremains) that helped specify the constructions located within the manor and its functioning.
\end{abstract}

Key words: deserted medieval village - manor farm - archaeological excavations - rural house - feudal residences.

\section{Pozdně středověký hospodářský dvi̊r v Rovném (okres Rokycany, Plzeňský kraj)}

Abstrakt: Předmětem několika sezon badatelského výzkumu se staly objekty předpokládaného hospodářského dvora v zaniklé středověké a časně novověké vesnici Rovný (k. ú. Drahoňův Újezd). Př́spěvek předběžně shrnuje dosavadní výsledky výzkumu, který se soustředil zejména na objekt dvojdílného domu a mohutného sklepa. Výzkum se opírá nejen o archeologický odkryv, ale také o aplikaci přirodovědných metod (geofyzika, rozbory půd, analýza makrozbytků), které vhodně doplňuji celkovou představu o zástavbě a fungováni dvora.

Klíčová slova: zaniklá středověká vesnice - poplužní dvůr - archeologický odkryv - vesnický dům - vrchnostenská sídla.

\section{Introduction}

Rovný represents one of the best-preserved Late Medieval - Post-Medieval rural settlement complexes in Bohemia. It consists of a deserted village with two settlement phases, mills, a moated site with a nearby manor farm, and the remains of its former surrounding agricultural land. The site, which is situated in a woodland area, was studied first using non-destructive methods as part of the research project concerning the historic settlement of the Rokycany District. Nearly thirty villages and several fortified manors deserted in the 15 th century, and some also in the 17th century (11 of them located in forested areas), have yielded extensive archaeological evidence (cf. Symonds-Vařeka, in print; Vařeka 2014; 2014a; Vařeka a kol. 2006; 2008; Vařeka-Holata-Rožmberský-Schejbalová 2011). Recently, smaller scale test excavations were implemented in Rovný, focusing on the manor farm. The preliminary results of this research are presented in this paper.

\section{Aims and methods}

The research is focused on assessing the settlement complex using non-destructive methods, which have been elaborated and tested during trial excavations. We focused on identifying the individual components of the site and the analysis of their attributes, as well as on determining the site's chronological phases. We used standard methods of topographic survey (Vařeka 2006), which were in certain areas accompanied by geophysical survey (H. Goodchild and R. Křivánek), drilling, phosphate sampling and metal-detector survey. The whole microregion was also investigated using LiDAR data analysis. Non-destructive research was complemented by small-scale excavations, the aim of which was to identify the two desertion horizons reflected in the documentary evidence and their character, chronology of the site based on the archaeological evidence, and to test interpretation possibilities of non-destructive methods. More specifically, the research concentrated on the following questions linked to lesser known archaeological 
site represented by the Late Medieval manor farm, the research of which focused on its layout and internal structure; forms and construction; function of buildings; identification of other features; and indication of higher social status reflected in material culture.

\section{Documentary evidence}

Rovný is first mentioned in documentary evidence dating back to 1367 ("Niclini de Rowny"; LC I/2, 81) and until 1466 it was owned by various members of the local low gentry (Sedláček 1889, 264-265). The Tax Register of the Pilsen Region from 1379 recorded a small estate composed of the two neighbouring villages, Rovný and Cetkov (both later deserted), belonging to a certain "Martin" (EIN BERNAREGISTER, 6). The only owner who has left more traces in written records was Lvík of Jivjany, who resided in Rovný ("Lwiconis de Gywyinn in Rowny residentis"; LC VII, 270; LC IX, 101; AČ VI, no. 29, 477-479). During the Hussite Wars, he was on the Catholic side, as was the majority of West Bohemian aristocrats. He also possessed a house in the royal town of Pilsen (Sedláček 1889, 265). Lvík ${ }^{1}$ is mentioned among other noble defenders of Pilsen during the long siege by united Hussite forces in 1433-1434. Devastation of his residence in Rovný and the whole village by Hussite troops, who plundered widely in and about the besieged Catholic town, cannot be ruled out. After these events, the village virtually disappeared from written sources for a whole century. Only the mill is mentioned in 1466 when it was connected to the large neighbouring estate of Zbiroh Castle (AMP, inv. no. 839 , cardboard 12).

Rovný appears again in 1543 as a part of another large nearby estate of Libštejn belonging to the Lords of Kolovraty. The property division record from this year mentions the village of Rovný with 4 peasants and a miller. The feudal residence consisting of a moated site ("tvrz") and a manor farm ("poplužni dvür") is mentioned as having been deserted. A detailed description records four defunct ponds in the village and its surroundings (NA, DZV 45 F 1 - F 1v). Documentary evidence from the late 16th century show several property changes and finally, in 1594, Rovný became part of the Zbiroh estate which was confiscated by Emperor Rudolph II (Sedláček 1889, 243). The village was deserted during the Thirty Years' War as several more villages around Zbiroh and elsewhere or were at least partly destroyed (Symonds-Vařeka, in print; Vařeka, in print).

\section{Surface survey}

The site is situated on the cadastral territory of Drahoňů Újezd (Distr. of Rokycany) in a shallow west - east oriented valley at an altitude of 432-454 $\mathrm{m}$ with a small unnamed stream flowing east to the larger stream of Koželuška. The shape of cadastral territory shows an extensive anomaly with two deserted villages (Cetkov and Rovný) in its southern area extending to a large forest complex. Apparently, settlement areas of both villages were annexed to the nearby parish village of Drahoňův Újezd (ca. $3 \mathrm{~km}$ away) after their desertion. The geological bedrock is formed by volcanic rocks, partly metamorphosed, Proterozoic to Palaeozoic (amphibolites, diabase, melaphyres and porphyries; www.cenia_geolog_geomorf.cz), which covers acidic brown earth (Tomášek 1995, 16).

Detailed surface survey of an area of $180 \times 370$ m (Fig. 1) has revealed two settlement components represented by a suzerain residence with surrounding areas and one village. An isolated mill with a millrace is situated ca. $100 \mathrm{~m}$ eastwards, and remains of fields, roads and mining areas have been traced around the site. An axis of the settlement complex is formed by the small stream which fills a complex cascade linking four ponds (distance between the lowermost and uppermost pond is $370 \mathrm{~m}$ and elevation reaches $11 \mathrm{~m}$ ). The moated site is situated on an artificial islet (Fig. $2 ; 22 \times 42 \mathrm{~m}$ ) in the middle of the third pond. A building with a rectangular floor plan

1 The name Lvík can be translated into English as "little lion". 


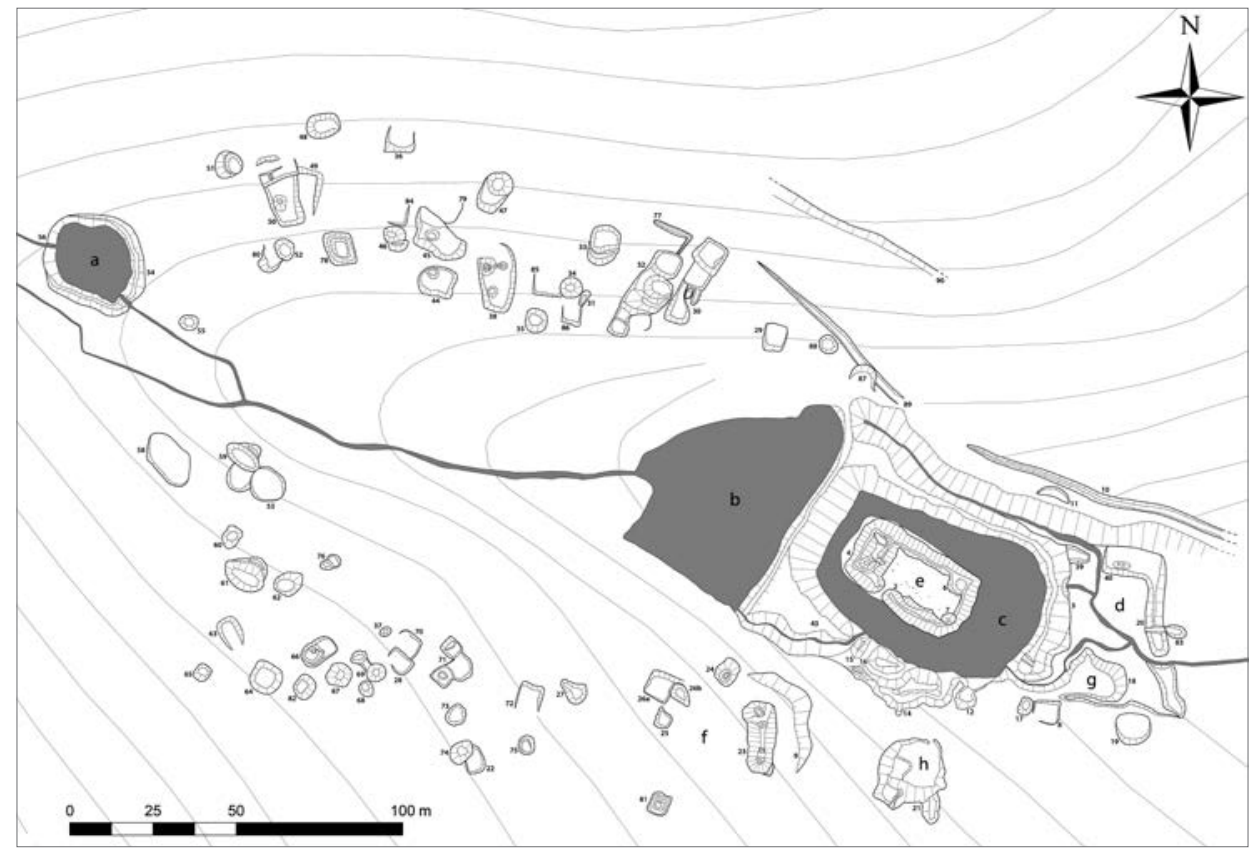

Fig. 1. Deserted village Rovný, Distr. of Rokycany. Numbers mark individual features; a-d - ponds, e - fortified manor, f - manor farm, $g$ - presumed Medieval mill, $h$ - quarry. Plan by P. Vařeka.

Obr. 1. Zaniklá vesnice Rovný, okr. Rokycany. Čísla označují jednotlivé objekty; a-d - rybníky, e - tvrz, f - hospodářský dvůr, g - předpokládaný středověký mlýn, h - lom. Plán P. Vařeka.

$(7 \times 14 \mathrm{~m})$ with possibly two rooms is located along the northwest side below the high dam of the second pond. Stone remains reaching up to $1-2.7 \mathrm{~m}$ indicate that the house was at least partially built with masonry (possibly a ground floor with some wooden superstructure?). Remains of the stone fortification wall can be seen along the edge of the rest of the islet with a simple gate at its south-western side. The north-eastern corner was reinforced by a tower and relief formations suggest that some other buildings of lighter construction had also been built along the south-western side. Recent disturbances revealed a burnt layer in several parts of the moated site indicating a catastrophic destruction layer. Surface remains of a manor farm adjacent to the moated site lie preserved on its south-western side (see below). A large pit southeast of the manor house is interpreted as a surface quarry, judging by geological survey, ${ }^{2}$ and was used as a source of building material for the moated site. A platform extending to the fourth, lowermost pond from the south may represent the remains of a mill $(18.6 \times 11.5-14.5 \mathrm{~m})$ and two other platforms situated on its northern side could have been used for some sorts of buildings connected with pond management.

The village consists of two rows of farm remains situated on gentle slopes above both the southern and northern side of the stream. The southern row is represented by a total of 18 mainly small- to middle-sized convex and concave shape features and terrace platforms indicating individual buildings. Hypothetically, four farmsteads of an irregular dispersed plan may be defined, reaching $25-35 \mathrm{~m}$ in width. Four square or rectangular platforms may be interpreted as one compartment of dwelling houses, representing the cores of farmsteads (features no. 64, 66, 71 and $72 ; 5.3 \times 5.8$ to $9.2 \times 9.3 \mathrm{~m}$ ). Other features are possibly the remains of outbuildings, i.e. one compartment of storage buildings, granaries, some equipped with cellars (concave shape fea-

2 Geological survey of the site was carried out by Jan Zavřel. 


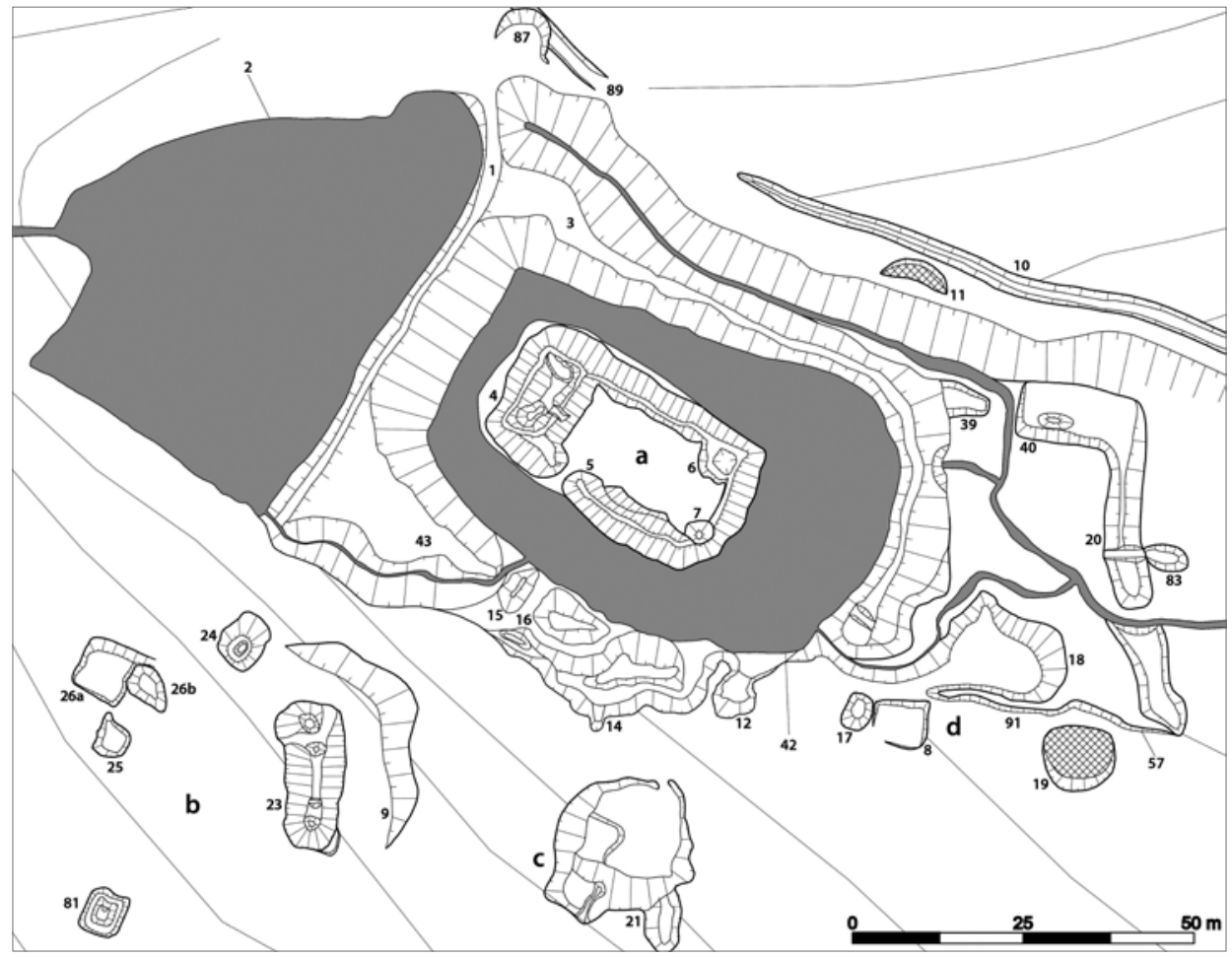

Fig. 2. Deserted village Rovný. Aristocratic residence in detail; a - fortified manor, b-manor farm, $c$ - quarry, $d$-presumed mill. Plan by $P$. Vařeka.

Obr. 2. Zaniklá vesnice Rovný. Detail vrchnostenského sídla; a - tvrz, b - hospodářský dvůr, c-lom, d-předpokládaný mlýn. Plán P. Vařeka.

tures); some other outbuildings and at least two features may represent small water reservoirs. Surface collection of pottery produced only Late Medieval ware and this dating corresponds also with the structure of the houses (small, one compartment, corner-timbered dwellings) typical for this part of the region in this period (Vařeka-Holata-Přerostová-Švejnoha 2008, 98; VařekaHolata-Rožmberský-Schejbalová 2011, 333-334). ${ }^{3}$ Several features connected with later mining activities were found in close proximity to the north-western side of the village, as well as a large charcoal burning kiln.

On the other hand, features forming the northern row are in a majority of cases of a different character, as they are better preserved and represent high and large platforms. Some of them are divided into separate parts, with marked deep concave shape features and in a few cases even remains of stone walls or foundations. Field walking yielded a collection of both Post-medieval pottery and Late Medieval ware, demonstrating two settlement phases of this part of the site. Four house plots may be defined, which have a wedge layout and reach about $40 \mathrm{~m}$ in their frontal area. The presence of large dwelling houses is a key element for identification of settlement components. These are three compartment houses built on terraced platforms $(8.5-11 \times 20-28 \mathrm{~m})$ with gables facing toward the village green. Remains of heating equipment placed in the front living room can be seen in two cases (features 38 and 50). Other features can be linked to outbuildings such as granaries (some equipped with cellars), cowsheds and one small water cistern

3 In addition to the Pilsen region, this archaic building tradition, represented by Late Medieval one-compartment corner-timbered dwelling houses equipped with a stone oven in a corner have also been found in southern Moravia (Belcredi 2006). 
were also found. In contrast to the regular orientation of the houses, the farms seem to have had an irregular plan. Subsequent mining activity has left 3 features that partially disturb the farm remains.

The second feature interpreted as a mill is situated ca. $150 \mathrm{~m}$ southeast from the village near the confluence of the two streams. The terrace platform with a half-oval plan $(10.6 \times 7.5 \mathrm{~m})$ is attached to the millrace, the length of which reaches $200 \mathrm{~m}$. It extends from dam remains of the deserted pond up the Koželuška stream.

\section{Trial excavations}

Surface remains of a manor farm are situated on an area of $46-52 \times 53 \mathrm{~m}$ in the southeastern part of the site adjoining the moated manor. A large, rectangular, possibly three-compartment building is indicated by a deep concave shape feature and is north-south oriented (feature no. 23: $10 \times 21.5 \mathrm{~m}$, depth $2.5 \mathrm{~m}$ ). Remains of another possible house are represented by a platform of a square plan (feature no. $26 \mathrm{a}: 6.6 \times 6.7 \mathrm{~m}$ ) and an attached sunken feature (feature no. 26b: $4.8 \times 7.8 \mathrm{~m}$; two-compartment house, eastern part equipped with cellar). Two other features of a square plan can be interpreted as outbuildings, possibly granaries (feature no. 24 : $6.5 \times 7.8 \mathrm{~m}$; no. $81: 5.8 \times 6.9 \mathrm{~m}){ }^{4}$

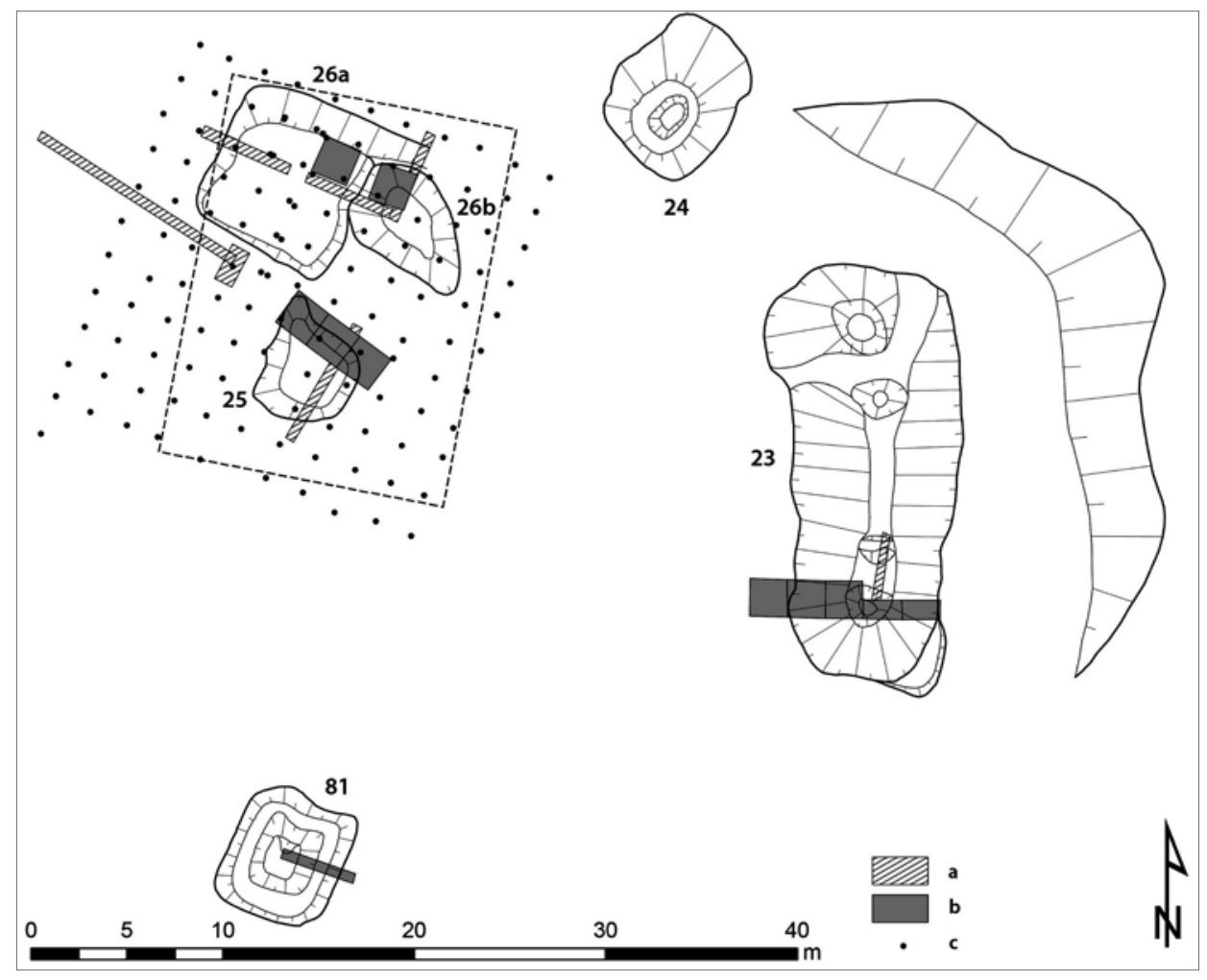

Fig. 3. Rovný - manor farm. Numbers mark features; a - excavations in 2013, b - excavations in 2014, c-coring. Plan by D. Novák and P. Vařeka.

Obr. 3. Rovný - hospodářský dvůr. Čísla označují objekty; a - odkryv v roce 2013, b-odkryv v roce 2014, c-pedologické vrty. Plán D. Novák a P. Vařeka.

4 The last manor farm's rectangular concave feature with sunken entrance (feature no. $25: 4.8 \times 5.2 \mathrm{~m}$ ) is situated two meters to the south of features $26 \mathrm{a}$ and $26 \mathrm{~b}$. 
At first, geophysical survey was carried out to test application possibilities of terrestrial magnetometer and resistance measuring at the site. ${ }^{5}$ The measurement covered nearly a quarter of the farm (a rectangle $20 \times 15 \mathrm{~m}$ ) and included features no. 25, 26a and 26b. G eo-electric resistance survey produced very biased results due to the very thin topsoil layer and specific subsoil attributes, esp. a high portion of stones. On the other hand, magnetometry was very successful in uncovering sections of topsoil with high magnetic values in spatial correlation with boundaries of features no. 26a and 26b, which later turned out to be layers of over-burnt clay and daub. Subsequently, a $2 \times 2 \mathrm{~m}$ grid was assessed in the area of the geophysical survey which was sampled by pedological drilling. A total of 130 soil samples documented topsoil layers (thickness and stratification) and were also used for phosphate sampling (Fig. 3). Drilling confirmed very high protruding subsoil and a sequence of layers was identified only at places with visible archaeological features (max. 4 strata). Topsoil thickness varied between 5 and $59 \mathrm{~cm}$ (average $21 \mathrm{~cm}$ ). Increase in phosphate values was documented in place of features no. 25 and $26 \mathrm{a}^{6}$

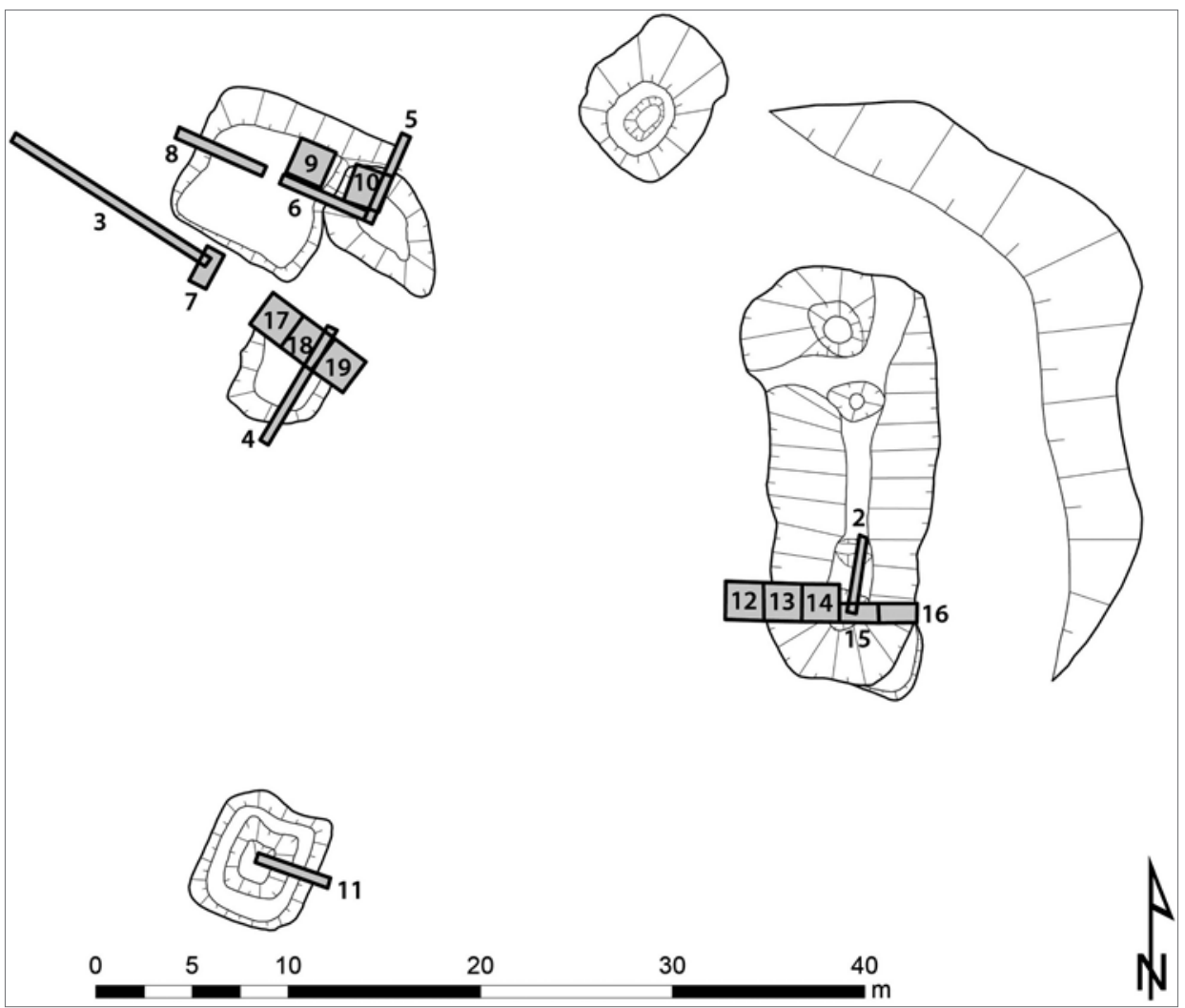

Fig. 4. Rovný - manor farm. Trial excavations. Numbers mark interventions. Plan by D. Novák and P. Vařeka. Obr. 4. Rovný - hospodářský dvůr. Zjišt’ovací sondáž. Č́ísla označují sondy. Plán D. Novák a P. Vařeka.

In 2013,8 narrow trial interventions were created ( $0.5 \mathrm{~m}$ wide; $2-12 \mathrm{~m}$ long) to make crosssections of selected features (no. 23, 25, 26a, 26b) and to test the adjacent area. In 2014, 10 square interventions $(2 \times 2 \mathrm{~m}$; two of them excavated only by half) and one narrow trench (cross-section

5 All the measurements were conducted by R. Křívánek (Institute of Archaeology AS CR, Prague). Equipment used: Sensys DLM-98-ARCH with five probes FMG650B (magnetometry) and Geoscan Research RM-15 (geo-electric resistance).

6 Analysis was performed by J. Hrdlička (Centre for New Technologies, University of West Bohemia). 
of feature no. 81) were opened (Fig. 4). Each stratigraphic layer except the topsoil was sampled and floated (201). ${ }^{?}$

\section{Large cellar (feature 23)}

The bottom of the large concave-shaped feature 23 was tested by intervention 2 in 2013; however, it was impossible to reach the floor due to a limited amount of space. Excavations continued in 2014 when a 1-2 m wide cut (interventions 12-16) from west to east was carried out in the southern part of the feature. Interventions unearthed a cellar reaching $2.7 \mathrm{~m}$ in depth and $4.5 \mathrm{~m}$ in width with $0.5-0.7 \mathrm{~m}$ thick walls built of clay-bound stones that were preserved up to $1.5-1.8 \mathrm{~m}$ (Figs. 5 and 6 ). The floor was formed by weathered rock with clay. A low stone foundation $0.5 \mathrm{~m}$ high and $1 \mathrm{~m}$ wide lined the western side of the cellar, possibly representing a base for surface construction of the building. A similar foundation can be assumed further east on the other side of the cellar. A layer filling the gap between the two walls was formed by relocated subsoil. The cellar was filled with destruction layers containing a large amount of burnt daub (at least $2.5 \mathrm{~m}^{3}$; 1,214 larger fragments; another 200 pieces of daub were found along the stone foundation outside the house) and stones from destroyed uppermost parts of walls $\left(2.6 \mathrm{~m}^{3}\right)$ giving proof of the building's destruction by wildfire.

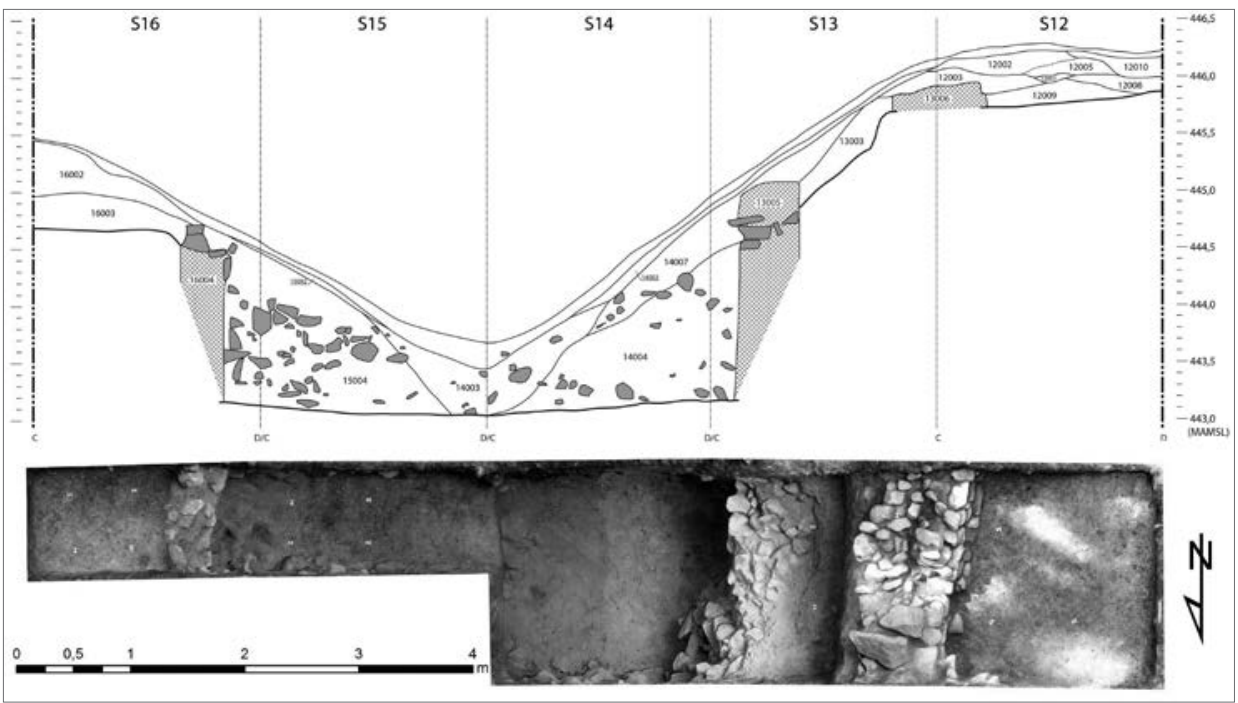

Fig. 5. Rovný - manor farm. Cross-section of the large building provided with a cellar (interventions 12-16). Plan and photogrammetry by $D$. Novák.

Obr. 5. Rovný - hospodářský dvůr. Řez velkým podsklepeným domem (sondy 12-16). Plán a fotogrammetrie D. Novák.

\section{Two-compartment house (features $26 a$ and $26 \mathrm{~b}$ )}

Topographic survey indicated a two-compartment house consisting of a surface part situated on a plane platform and an adjacent sunken area (Fig. 7). Magnetometric measurements showed the presence of layers exposed to a great heat, which created a rectangular anomaly correlating spatially with the suggested walls of the building. The sequence of orthogonally oriented interventions aimed to provide a longitudinal and cross section through the building as well as to analyse the strongest anomalies detected by geophysical prospection (2013; interventions 5, 6 and 8$)$ and to unearth part of the house containing the assumed heating equipment (2014; interventions 9 and 10; Fig. 8). Excavations yielded a $1 \mathrm{~m}$ wide and $0.3 \mathrm{~m}$ high stone foundation lined

7 Flotation was implemented by A. Fischer (University of Amsterdam), who is currently analysing the botanical macro-remains. 


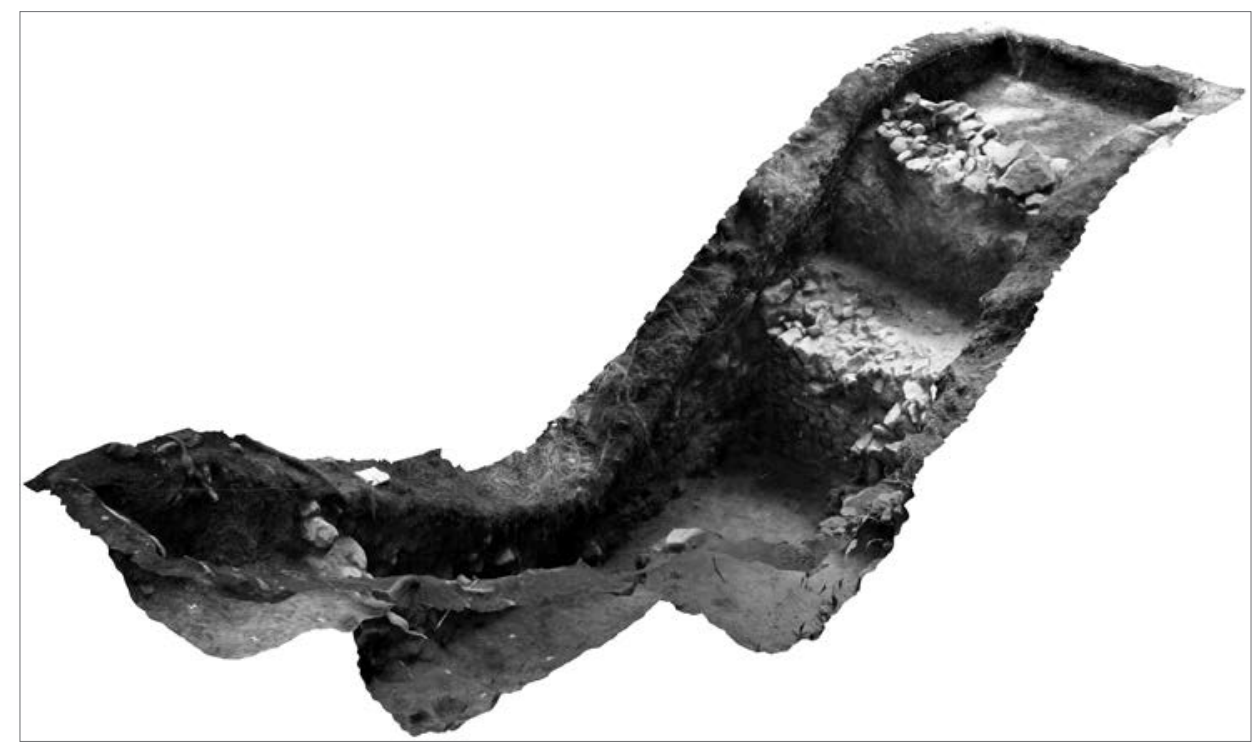

Fig. 6. Rovný - manor farm. Cross-section of the large building provided with a cellar - 3D model. Model by D. Novák. Obr. 6. Rovný - hospodářský dvưr. Řez velkým podsklepeným domem - 3D model. Model D. Novák.

along the edge of the platform and an adjacent cellar with a stone revetment. The floor of the foundations was not reached due to limited space and other safety reasons. The roots of a large spruce were found to have disturbed the area between the surface and sunken part of the building, making it impossible to document the supposed connection between the constructions. The surface part of the building was furnished with a circular stone oven situated in the north-east corner with a diameter of $2 \mathrm{~m}$. Only the topmost part of the oven was uncovered and documented, with no further interventions made into the construction itself. Excavations demonstrated a destruction horizon that left a sequence of layers with burnt daub (865 larger pieces) and charcoals from the wooden constructions of walls, a ceiling and roof structure that collapsed both into the interior and exterior of the building (Fig. 9). Destruction layers covered the surface part and also filled the cellar.

\section{Feature of an uncertain function (feature 25)}

Interventions 4 and 17-19 tested the concave-shaped feature 25 in an attempt to identify its function and possible link to a nearby house. The plan of the sunken feature is rectangular, $3 \mathrm{~m}$ in width, and has a ca. 1m-wide sunken staircase running from its north-west corner toward the surface part of the house. Stair-steps were cut into the subsoil and covered with stone remains of an unknown origin (perhaps a surface construction of some kind?). In the north-east corner a ditch $0.5 \mathrm{~m}$ wide was found extending outside the feature and corresponding with a magnetic anomaly detected by magnetometric survey. Sides of the sunken feature were very unevenly shaped with a gradual slope and covered with eroded subsoil. The fill of the feature, also containing a large portion of stones of different size $(10-50 \mathrm{~cm})$, did not show as much evidence of fire as other excavated structures (128 small pieces of burned daub were found; Fig. 9).

\section{Outbuilding (feature 81)}

Intervention 11 focused on relief formation that was interpreted as an outbuilding of some kind, perhaps a granary (feature 81). Excavations traced a 1m-wide clay-bound stone foundation covered with a layer of burnt daub (230 larger pieces were recovered, mostly from the interior) 


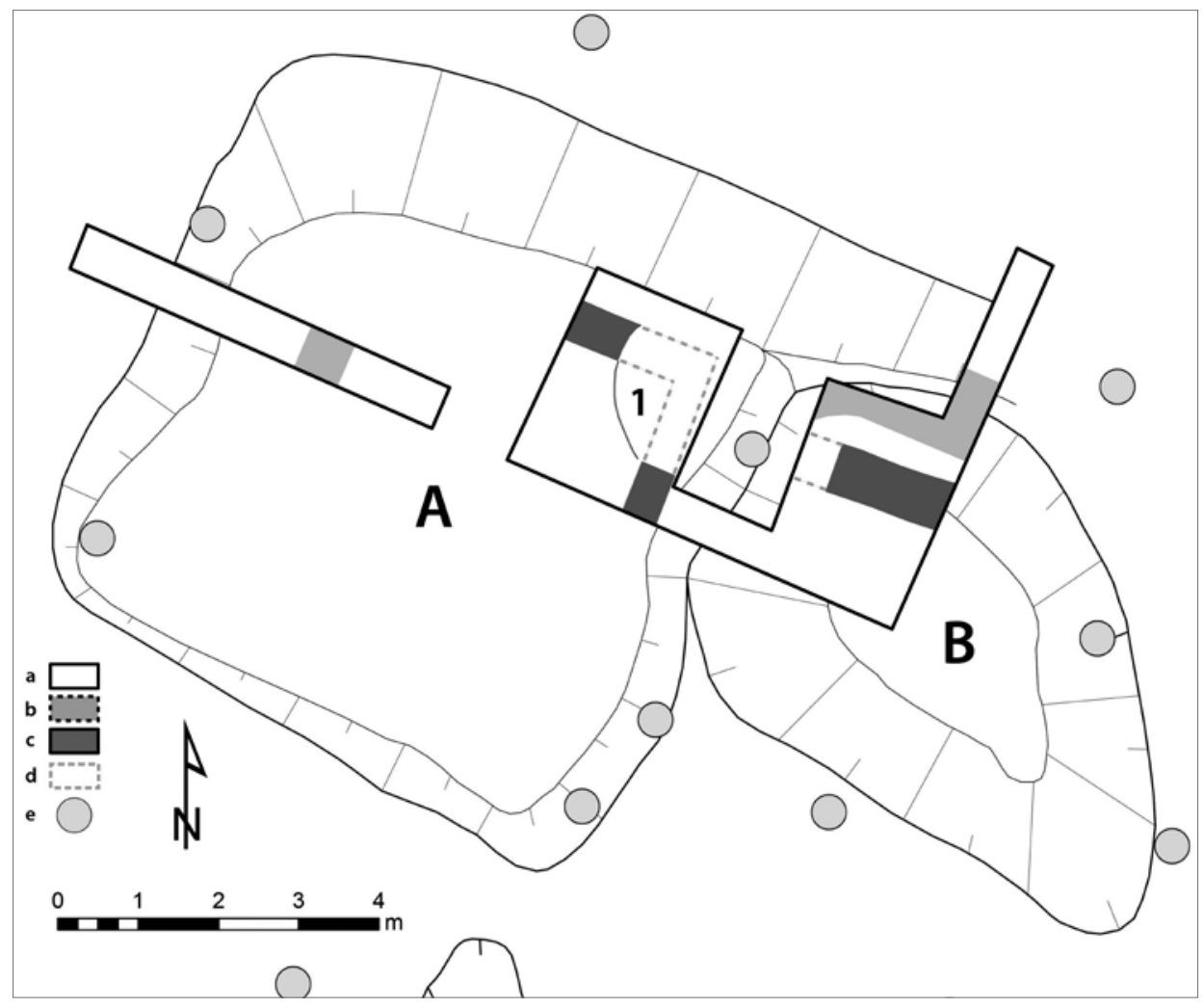

Fig. 7. Rovný - manor farm. Feature no. 26 (two-compartment house); A - living part, B - storage part, a - interventions, $\mathrm{b}$ - indications of not preserved foundations, $\mathrm{c}$ - stone foundations, $\mathrm{d}$ - presumed stone foundations (unexcavated), $\mathrm{e}$ - trees, 1 - stone oven. Plan by D. Novák and P. Vařeka.

Obr. 7. Rovný - hospodářský dvůr. Objekt č. 26 (dvojdílný dům); A - obytná část, B - skladovací část, a - sondy, b - pravděpodobný prủběh stěn, $\mathrm{c}$ - pozůstatky podezdívky, $\mathrm{d}$ - předpokládané podezdívky (nekopáno), e - stromy, 1 - kamenná pec. Plán D. Novák a P. Vařeka.

indicating a wooden superstructure (Fig. 10). The earthen floor was covered by a thin layer of sandy clay. No pottery or other artefacts were found.

\section{Finds}

Archaeological excavations yielded a total of 1,169 ceramic fragments, 2,859 pieces of burnt daub (some with construction imprints), 40 iron items, 51 samples of carbonised wood and three bricks. Numerous floated samples with botanical macro-remains and other ecofacts, which are currently being processed, show extensive potential for environmental analysis.

Pottery is represented by coarse, hard fired, fast wheel-thrown blue-grey ware $(1,100$ pieces). The most numerous finds were obtained in feature 25 (60\% in weight and $73 \%$ in number) and a comparable amount was gained in both the large house $(24 \% \text { and } 13 \%)^{8}$ and the two compartment houses (15\% and $14 \%$ ). Only 132 pieces of pottery can be assigned to individual vessel types. Cooking and storage pots of different size (55\%) and lids (34\%) are most strongly represented, followed by jugs $(8 \%)$, conical bowls $(2 \%)$ and tripods $(1 \%)$. Only 5 pieces $(19 \mathrm{~g})$ belong to fine-grained thin ware representing table drinking vessels and one fragment $(3 \mathrm{~g})$ is

8 Cellar fill produced 202 fragments of pottery and 112 ceramic shards were found outside the house along the stone foundation. 


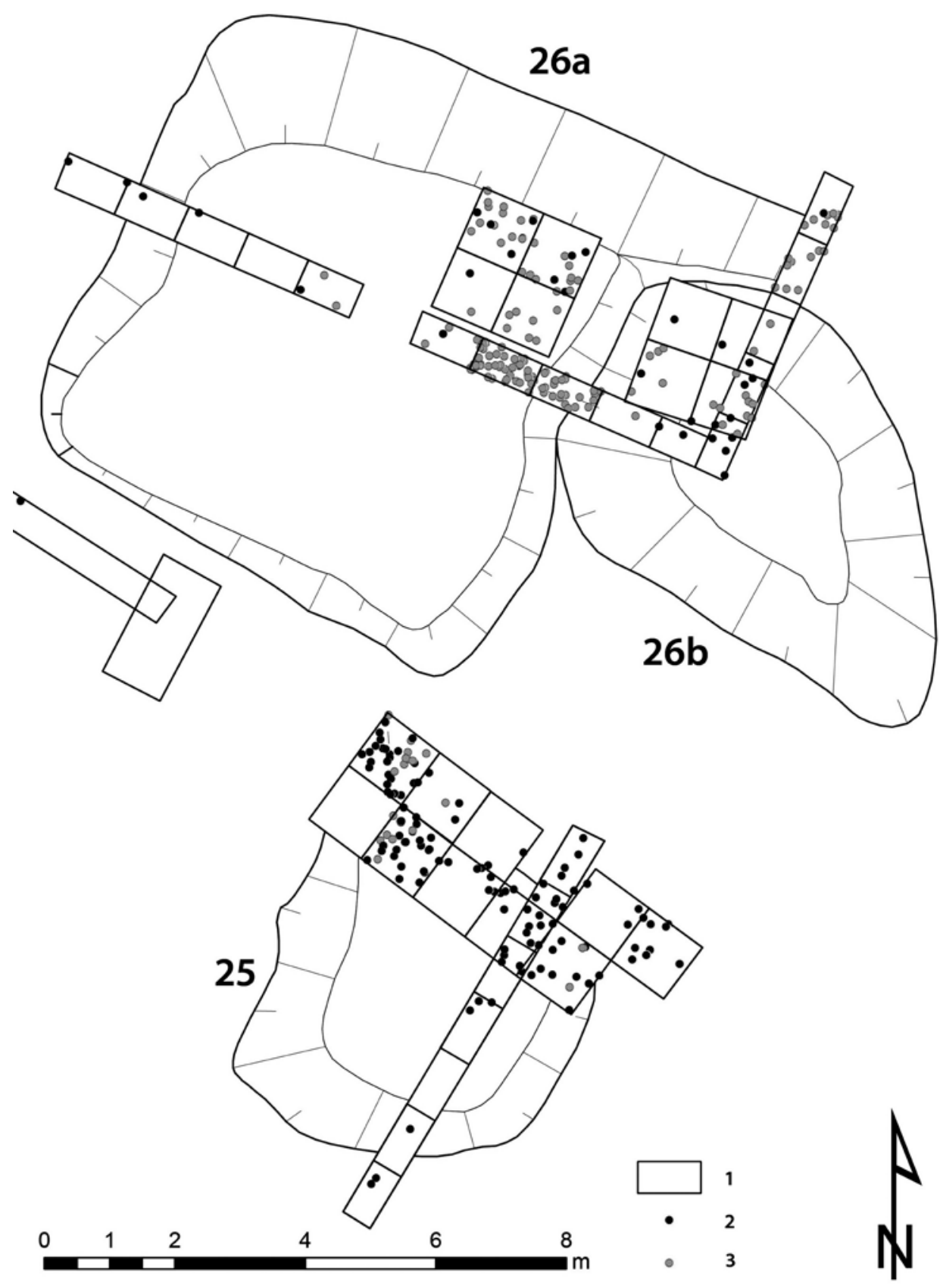

Fig. 8. Rovný - manor farm. Feature 26 (two compartment house). 3D model of the stone oven situated in the north-east corner (intervention 9). Model by D. Novák.

Obr. 8. Rovný - hospodářský dvưr. Objekt č. 26 (dvojdílný dům). 3D model pozůstatků kamenné pece v severovýchodním rohu (sonda 9). Model D. Novák. 


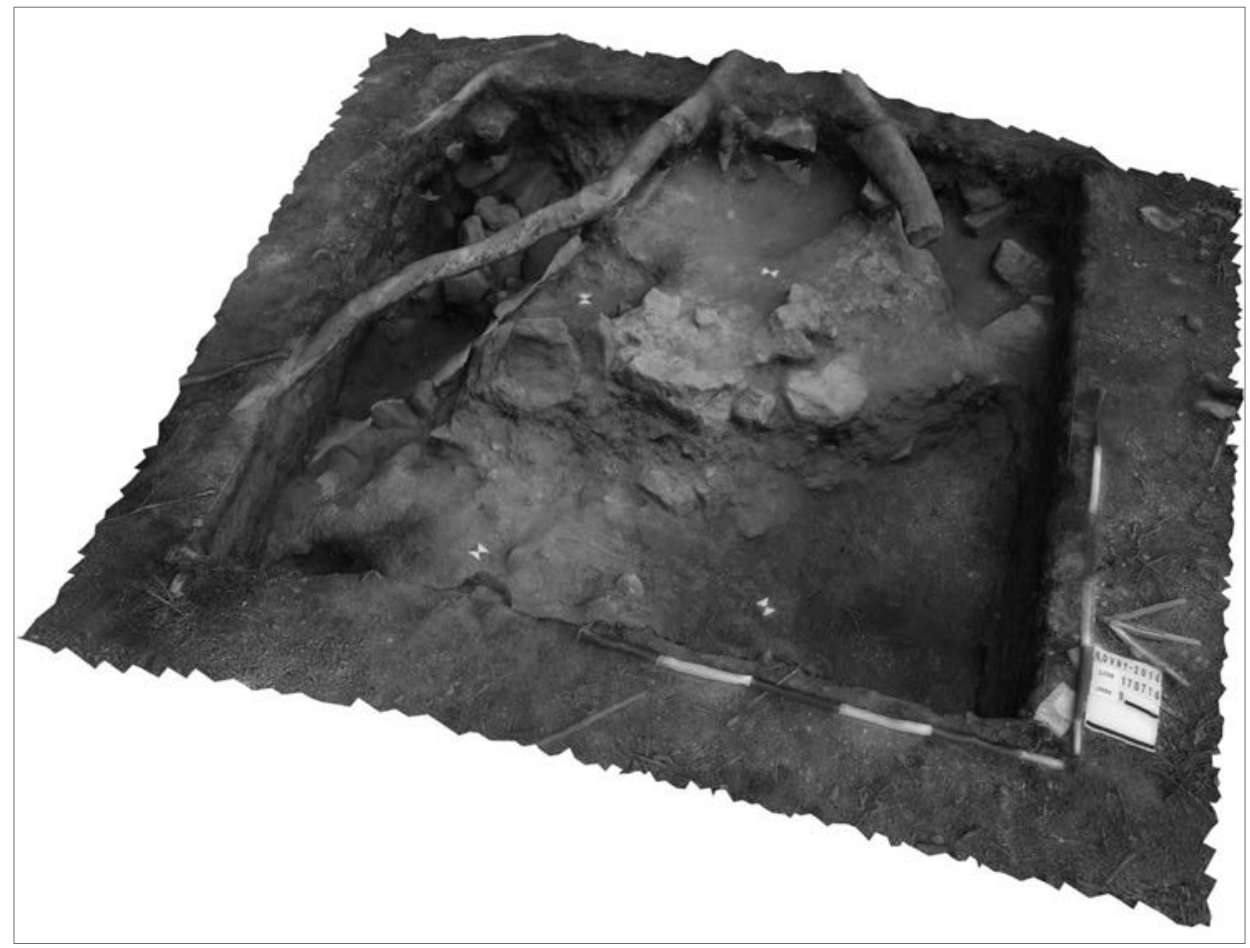

Fig. 9. Rovný - manor farm. Features 25 and 26.1 - intervention sectors with finds, 2 - pottery finds, 3 daub finds $(1$ dot $=$ 5 pieces). Plan by $D$. Novák.

Obr. 9. Rovný - hospodářský dvůr. Objekty č. 25 a 26. 1 - odkryté sektory s nálezy, 2 - zlomky keramiky, 3 - zlomky mazanice (1 bod = 5 kusů). Plán D. Novák.

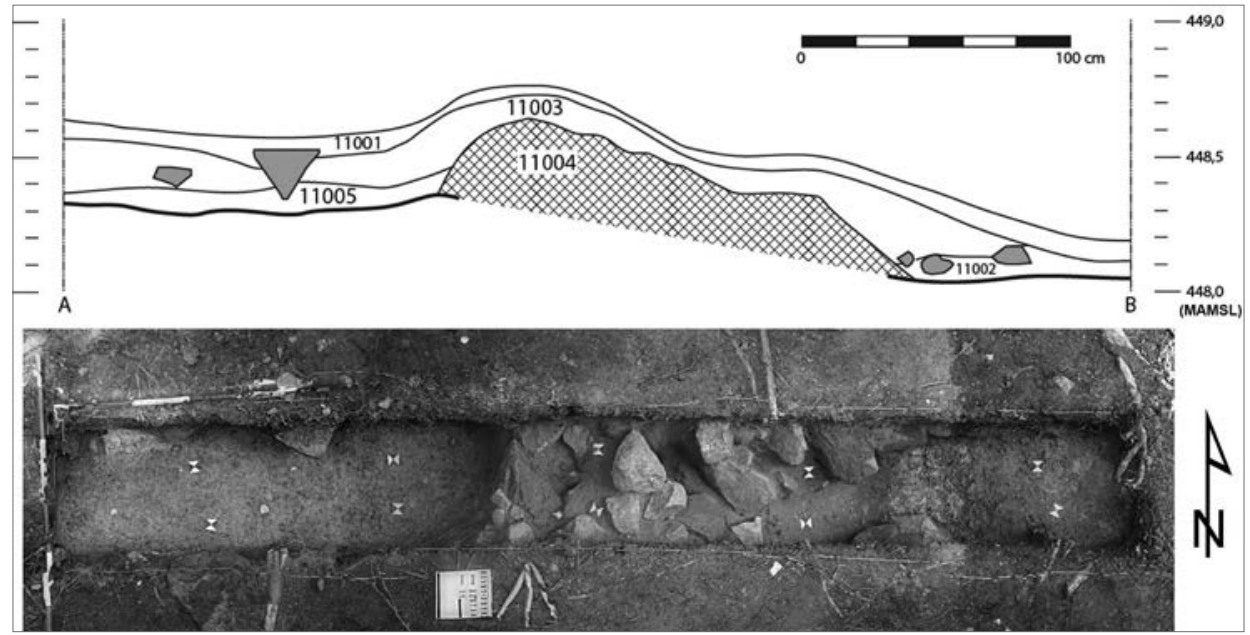

Fig. 10. Rovný - manor farm. Cross-section of the outbuilding (intervention 11). Plan and photogrammetry by D. Novák. Obr. 10. Rovný - hospodářský dvůr. Řez hospodářským objektem (sonda 11). Plán a fotogrammetrie D. Novák. 
attributed to white-yellow ware with a lead glaze. Two spindle whorls were made from ceramic lid knobs (feature 25). A small fragment of perforated stove tile decorated with architectural motifs was found in the two-compartment house. Iron finds were mostly undeterminable with the exception of one horseshoe and several nails.

\section{Interpretation and discussion}

It seems that Rovný was founded at a late stage of the Radeč upland settlement process during the early 14th century, which could have originally formed part of the royal hunting forest stretching up to the Křivoklát region (Vařeka-Holata-Rožmberský-Schejbalová 2011, 328). ${ }^{9}$ The village probably consisted of two rows of a total of eight farms aligned along the stream. The remains of the Late Medieval village seem to have been preserved intact in the southern part of the site. A remarkable network of four ponds was built on the watercourse, which gives evidence of the considerable technical and construction skills of its builders. The upper pond above the village retained water under the spring of the small stream and the other three were involved in the fortification of the moated site, which was built on an islet in the third pond. A gate located in the south wall faced the adjacent manor farm. A small mill probably constituted part of its surrounding areas.

This region, as well as the entire surrounding area of Rokycany and Pilsen, saw a significant population reduction during the 15th century, leading to the desertion of almost $40 \%$ of the villages there. This process is commonly linked to the Hussite Wars, which plagued the predominantly Catholic Pilsen region with countless military campaigns (Vařeka-Holata-RožmberskýSchejbalová 2011, 330). Both archaeological survey and excavations demonstrated fire extinction of the whole site producing a significant, archaeologically registered burnt horizon. The village was partly re-established in the early 16th century and consisted of only one row of four farms in the northern part, where more recent building activities replaced earlier structures. We assume that a newer mill was located more conveniently on a larger stream in a deep valley east of the village.

Rovný is one of the few residences of the low gentry in Bohemia and Moravia that has been archaeologically investigated. The site consists of both a fortified manor and manor farm forming a unified complex with hierarchically arranged functions projected into the layout. ${ }^{10}$ Contrary to numerous moated sites formed by only a single tower building, ${ }^{11}$ the fortified manor in Rovný is a representative and exemplary residence. ${ }^{12}$ Its area of $24 \times 35 \mathrm{~m}$, protected by a stone wall fortified with a corner tower, housed a stone-built palace (at least on its ground floor) of $7 \times 14 \mathrm{~m}$ and some wooden service outbuildings. The residence situated on an islet was sheltered by a cascade of ponds with a sophisticated system of side channels. The manor farm, enabling own-account farming, was annexed on the south-western side and was likely connected to the residence by a wooden bridge. The fragmentary testimony of written evidence shows that Rovný was a small domain owned by members of the low gentry, which also included the neighbouring village of Cetkov in the late 14th century (see above). In addition to the annuities (the amount of which in the Later Middle Ages is unknown) ${ }^{13}$ collected from subjects living on roughly eight archaeologically documented farms, agricultural production organized in the manor farm

\footnotetext{
9 Most recent finds suggest that village origins may be even older (13th century; based on pre-procession of pottery from excavation in the summer 2015)

10 E. g., Hradečno (Novák-Vařeka 2014, 446), Kř́i (Klír 2014), Lažany (Smetánka-Klápště 1981), Mstěnice (Nekuda 1985) or Ostrov (Smetánka-Klápště-Richterová 1979). The second type of these residences are manor farms without any moated site, which formed a part of nucleated villages (e. g., Svídna - Smetánka 1988, 27) or were situated as isolated components of a settlement pattern (e.g., Nevězeň - Vařeka 2008; Olešná - Vařeka 2014; Rychvald - Kypta-Laval-Neustupný-Šimůnek 2012). In some cases, a defence tower was placed within the area of the unfortified manor farm (e.g., Džbánek and Třebekov - Anderle-Rožmberský-Švábek 1993; Staré Zámky by Libušín - Novák-Vařeka 2014, 453-454)

11 E. g., excavated sites Koválov (Unger 1994) and Tlesky (Nechvátal-Radoměrský 1963).

12 Typology of fortified manors in Bohemia cf. Chotěbor 1982; 1989; Svoboda 1998.

13 Written records from the Early Modern period provide some comparative evidence; Four peasants from Rovný paid 63 silver groschen monetary rent in 1543 (NA, DZV 45 F 1 - F 1v) and 675 silver groschen before the Thirty Years' War (SOA Prague, Velkostatek Zbiroh, inv. no. 1, fol. 517-519).
} 
provided an important (if not the main) source of income for the knights of Rovný. Both nondestructive research and targeted excavations have elucidated the layout, structure, construction, function of individual components, and material culture of the manor farm in the 14th and early 15 th centuries. Its size is estimated at about $50 \times 50 \mathrm{~m}$ and consisted of at least four buildings. The largest one was situated on the north-west side. Excavations showed that the house was equipped with a large stone-built cellar. However, the amount of stone remains in its fill did not correspond to the collapsed vaulting but only the upper parts of the walls. Therefore, we may assume there was a flat wooden ceiling serving also as the flooring of the ground floor. The shape of the relief formation suggests three compartment divisions of the cellar consisting of two smaller side parts and a large central part. Layers of burnt daub deposited in the cellar indicate wooden surface walls of the house that rested on stone foundations lining the cellar, which was revealed in intervention 12. Bricks found in the cellar's fill may point to the heating equipment of the house. The total size of the building can be estimated at ca. $9 \times 22 \mathrm{~m}$. We suppose that the large building was the administrative centre of the domain and also the centre of own-account agricultural activities; however, it may have been used by the owner of the domain for some purpose. Its total area was a single-size larger than the masonry-built palace in the fortified manor, but it contrasted to it with its poor quality stone-laying and timber, very likely block surface construction. No story arrangement of the large timber house can be assumed due to the limited amount of the daub destruction, contrary to the palace, which very likely had more than one floor. ${ }^{14} \mathrm{~A}$ large basement is proof of the considerable storage capacities used for food and beverages which were not available in the fortified manor, where the construction of any cellar was practically impossible due to a high level of underground water. The two-compartment building situated in the north-west part of the manor farm can also be interpreted as a dwelling house, though of a lower standard. It corresponds with rural houses documented in deserted Late Medieval villages in some parts of the Pilsen region. It consisted of a square living room (ca. $6 \times 6 \mathrm{~m})$ equipped with a stone oven situated in a corner and an adjacent story part (ca. $4 \times 7 \mathrm{~m}$ ) with a lower storage room set partly to the ground and upper room, probably used as a chamber. Burnt debris containing numerous daub fragments with construction imprints demonstrated corner-timbered walls based on stone foundations. Some parts were also built using wattle-and-daub construction (perhaps gables?). We assume that the building housed the manor farm administrator (Czech šafár, Latin colonus; Graus 1953, 246-247; 1957, 207) and his family and provided not only dwelling functions but also storage capacities for private agricultural products.

Sunken feature 25 situated next to the two-compartment house may have served a production purpose of some kind. The lower part was accessible by a sunken staircase from the northwest and a drain led from the north-east side. Stone remains deposited in the fill of the feature indicate some structure and a small amount of burnt daub gives evidence of only a light wooden superstructure. The large concentration of pottery fragments (more than $50 \%$ of the total obtained ceramic finds) may show its original location and use. Hypothetically, we can assume e. g. the placement of a drying-kiln in this sunken feature (analogously Mstěnice; see Nekuda 1985). On the other hand, we cannot exclude secondary use of the feature as a refuse pit.

An outbuilding indicated by feature 81 probably closed the area of the manorial farm on the south-west side. It was very likely a square-plan building with timber walls resting on stone foundations. We can assume this building had a storage function; however, the nature of the stored commodities can be identified only by ongoing botanical research. Absence of finds may indicate storage containers that leave no direct archaeological traces (e. g. bags?). A similar function can also be assumed in feature 24 , which was not tested by excavations.

Pottery finds are typical of the Pilsen region in the late 14th - early 15th century; however, it appears that pots and related lids are over-represented in Rovný, while finds of fine tableware

14 This assumption is based on Late Medieval standing fortified manors, whose palaces regularly had three storeys. The ground floor was used for storage facilities, while the first floor was used for a representative dwelling room/rooms (sometimes also for a kitchen) and the third floor included chambers (cf. Sudkův Důl - Chotěbor 1990; Dolany - Anderle-Procházka-Švábek 1984; Lštění - Procházka 2008; Nekmíř Švábek 1984). 
are low. Two spindle whorls indicate the home production of textile yarn. The isolated find of a richly decorated stove tile is surprising in this context, as we have no evidence of any developed type of heating equipment in the form of a stove in the excavated manor farm. We assume it may have been brought from somewhere else and given a secondary use, e. g. a game token. Generally, movable artefacts do not reflect any higher social status and this evidence is fully comparable with the rural environment. ${ }^{15}$

Rovný represents one of a very few Late Medieval manorial farm sites in Bohemia systematically studied using archaeological methods, including excavations ${ }^{16}{ }^{\text {The only completely }}$ excavated comparative site dated to the same period can be found in the deserted village of Mstěnice in Moravia (Vysočina Region, Distr. of Třebíč; Nekuda 1985). Large scale excavations traced a fortified manor with adjacent manor farm with a regular rectangular plan $(25 \times 40 \mathrm{~m})$ with a four-winged core. The building, apparently used by a manor administrator, was made up of an ordinary three compartment rural house $(5 \times 14 \mathrm{~m})$ similar to those excavated in the nearby village and consisted of a living area furnished with a stone oven, entrance and storage area. Farm labourers may have used outbuildings set around the courtyard, one of which was furnished with a hearth or unpreserved oven. In contrast with Rovný, archaeological evidence proved various functions of some farm buildings as stables, an annexed smithy, drying-kiln and barn.

\section{Conclusions}

Rovný belongs to villages that were probably established in the Radeč highlands as late as the early 14th century, when the settlement network of the Rokycany region was completed. A residence of a member of the low gentry was founded in the village representing an administrative centre of a very small estate consisting of 1-2 villages. Such small domains were numerous in the region as well as seats of the low gentry documented by written and archaeological evidence, whose total number exceeds fifty. A significant reduction in settlement occurred in the 15 th century, during which nearly $40 \%$ of the villages deserted (of which only a quarter has been re-established in the 16th century) as well as number of fortified manors, manor farms and castles were ruined and abandoned. Like elsewhere in Bohemia, settlement reduction might be linked to the devastating effects of the long Hussite Wars that heavily affected the Pilsen region. Archaeological investigation of several sites in the Rokycany region, including Rovný, has shown evidence of a catastrophic fire extinction horizon and its partial repopulation in the 16th century. This process corresponds with conclusions generally outlined by E. Maur (2013), who describes a vast depopulation of the post-Hussite Pilsner region.

Survey and excavations using a wide range of methods seem to be a reasonable way to get a novel insight into a local rural settlement in its full complexity. Rovný allow us to study a complete settlement unit with several different activity areas used by the specific social groups. Further research will focus on environmental samples processing and will apply further methods on the whole area of the manor farm (esp. further geophysical methods, drilling, phosphate and other soil analysis and metal detector survey). A prominent topic on the site is also a comparison of two desertion horizons, the 15th century and the 17th century. Most recent excavation of one of the early modern homesteads (deserted in the 17th century) shows a surprising continuity of spatial distribution of buildings, however, results are very different from medieval contexts in many aspects, including clues on building materials and subsistence strategies represented by macrobotanical remains. Furthermore, attention will be paid to the moated site itself in order to

15 E.g., finds from an excavated farm in the nearby deserted village of Sloupek dated to the same period (Vařeka, in preparation). 16 Few excavated sites were only partly preserved and their publications are of a preliminary character (Hrnčíre - Meduna 2006) or have not been published yet (Prague - Ruzyně and Prague - Třeboradice; we are grateful for information provided by D. Daněček and M. Bureš). Other sites preserved in woodlands dated to the same period were only surveyed; e. g., Hradečno, Humniště (Novák-Vařeka 2014, 446-447), Ostrov (Smetánka-Klápště-Richterová 1979), Lažany (Smetánka-Klápště 1981), Olešná (Vařeka 2014), Nevězeň (Vařeka 2008) and Rychvald (Kypta-Laval-Neustupný-Šimůnek 2012). 
compare its artefactual equipment and building forms with the manor farm. We can expect more interesting results coming soon.

\section{Documentary evidence}

AČ VI: Archiv český čili staré písemné památky české i moravské VI (Palacký, F., ed.). Praha 1872. AMP: Archiv of the City of Pilsen; collection of historical charters.

EIN BERNAREGISTER: Ein Bernaregister des Pilsner Kreises vom Jahre 1379 (Emler, J., ed.). Prag 1876.

LC I/2: Libri confirmationum ad beneficia eccleastica pragensem per archidioecessim I/2. (Emler, J., ed.). Pragae 1874.

LC VII: Libri confirmationum ad beneficia eccleastica pragensem per archidioecessim VII (Emler, J., ed.). Pragae 1886.

LC IX: Libri confirmationum ad beneficia eccleastica pragensem per archidioecessim VIII, IX, $\mathrm{X}$ (Emler, J., ed.). Pragae 1889.

NA, DZV: National Archive Prague; Collection Desky zemské větší (Provincinal boards).

SOA Prague: State Regional Archive Prague, Great-estate Zbiroh 1652, inv. no. 1.

\section{Literature}

ANDERLE, J.-PROCHÁZKA, Z.-ŠVÁBEK, V., 1984: Dolany, o. Klatovy, Ročenka Klubu Augusta Sedláčka 84, 73-83.

ANDERLE, J.-ROŽMBERSKÝ, P.-ŠVÁBEK, V., 1993: Výsledky povrchového průzkumu cisterciáckých dvorů na Plzeňsku - Ergebnisse der Oberflächenerkundung von Zisterzienserhöfen in der Gegend Plzeň, CB 3, 261-270.

BELCREDI, L., 2006: Bystř̌ec. O založení, životě a zániku středověké vsi. Archeologický výzkum zaniklé středověké vsi Bystřec 1975-2005. Brno.

GRAUS, F., 1953: Dějiny venkovského lidu v Čechách v době předhusitské, I. Dějiny venkovského lidu od 10. stol. do první poloviny 13 . stol. Praha.

- 1957: Dějiny venkovského lidu v Čechách v době předhusitské, II. Dějiny venkovského lidu od poloviny 13. stol. do roku 1419. Praha.

CHOTĚBOR, P., 1982: K situaci a stavební podobě vesnických feudálních sídel - Zur Situation und Bauart der Feudalsitze auf dem Lande, AH 7, 357-366.

- 1989: Nejstarší období výstavby českých tvrzí - Der älteste Zeitabschnitt des Ausbau der tschechischen Festen (bis zur Hälfte des 14. Jahrh.), AH 14, 257-270.

- 1990: Rekonstrukce obytné místnosti tvrze v Sudkově dole - Die Rekonstruktion eines Wohnraums der Feste in Sudkův důl, AH 15, 217-222.

KLÍR, T., 2014: Zur Problematik der sogenannten Endphase der hochmittelalterlichen Kolonisation und zu den Siedlungsformen in Böhmen: Die Wüstung Kř́i bei Sadská (Mittelböhmen), Praehistorica 31/2, 373-403.

KYPTA, J.-LAVAL, F.-NEUSTUPNÝ, Z.-ŠIMŮNEK, R., 2012: Osamocený dvůr s opevněným sídlem v pozdním středověku: Rychvals u Dřevíče (okr. Rakovník) a jeho analogie - An isolated Late Middle Ages farmyard with a fortified residence: Rychvald near Dřevíč (Central Bohemia) and its analogies, AR LXIV, 549-570.

MAUR, E., 2013: Pustnutí vsí na Plzeňsku za pozdně středověké agrární deprese. In: Stočes, J.-Mušková, E. a kol., Tenkrát na západě (Čech): Kapitoly z dějin kultury a každodennosti Plzně a Plzeňského kraje, 49-66. Plzeň.

MEDUNA, P., 2006: Hrnčíře, zaniklý dvůr Oseckého kláštera - Hrnčíře, der untergegangene Hof des Klosters in Osek, CB 10, 245-256.

NECHVÁTAL, B.-RADOMĚŘSKÝ, P., 1963: Archeologický výzkum na tvrzi v Tleskách u Jesenice (okr. Rakovník) - Eine archäologische Grabung auf der Feste in Tlesky bei Jesenice (Bezirk Rakovník), ČNM A CXXXII, 4-13.

NEKUDA, V., 1985: Mstěnice 1. Zaniklá středověká ves u Hrotovic. Hrádek - tvrz - dvůr - předsunutá opevnění. Brno.

NOVÁK, D.-VAŘEKA, P., 2014: Tvrze na Kladensku - Festen in der Region Kladno, AH 39, 439-471. 
PROCHÁZKA, Z., 2008: Tvrz ve Lštění - pět let výzkumů a rekonstrukcí (2002-2006) - Lštění - Fünf Jahre der Forschungen und Rekonstruktionen (2002-2006), CB 11, 367-388.

SEDLÁČEK, A., 1889: Hrady, zámky a tvrze Království českého VI - Podbrdsko. Praha.

SMETÁNKA, Z., 1988: Život středověké vesnice. Zaniklá Svídna. Praha.

SMETÁNKA, Z.-KLÁPŠTĚ, J., 1981: Geodeticko-topografický průzkum zaniklých středověkých vsí na Černokostelecku - Geodetical-topographical survey of deserted medieval villages in the Kostelec-nadČernými-lesy region, PA LXXII, 416-458.

SMETÁNKA, Z.-KLÁPŠTĚ, J.-RICHTEROVÁ, J., 1979: Geodeticko-topografický průzkum zaniklé středověké vsi Ostrov (k. o. Jedomělice) - Geodetical-topographical survey of deserted medieval village Ostrov, AR XXXI, 420-430.

SVOBODA, L., 1998: Stavební vývoj českých tvrzí. In: Encyklopedie českých tvrzí. I. díl (A-J), XIXXXIII. Praha.

SYMONDS, J.-VAŘEKA, P., in print: Peasants and Soldiers: An Archaeology of Villages Deserted During the Thirty Years' War in Bohemia. In: Proceedings of the Conference "The Archaeology of Violence: Wartime Violence, Mass Violence". Irap - La Découverte.

ŠVÁBEK, V., 1984: Nekmíř, o. Plzeň-sever, Ročenka Klubu Augusta Sedláčka 84, $28-34$.

TOMÁŠEK, M., 1995: Atlas půd České republiky. Praha.

UNGER, J., 1994: Koválov. Šlechtické sídlo z 13. století na jižní Moravě. Brno.

VAŘEKA, P., 2014: Zaniklý pozdně středověký dvůr u Olešné na Rokycansku, Archeologie západních Čech 8, 134-143.

- 2014a: Zaniklá středověká a časně novověká ves Rovný na Zbirožsku (okr. Rokycany), Archeologie západních Čech 7, 131-143.

- in print: Archeologický výzkum vsí zaniklých v době třicetileté války na Rokycansku (Plzeňský kraj), Studies in Post-medieval Archaeology 5.

- in preparation: Deserted Late Medieval Village Sloupek in West Bohemia.

VAŘEKA, P. a kol., 2006: Archeologie zaniklých středověkých vesnic na Rokycansku I -Archeology of Deserted Medieval Villages in the Rokycany Region (West Bohemia). Plzeň.

- 2008: Archeologie zaniklých středověkých vesnic na Rokycansku II - Archaeology of Deserted Medieval Villages in the Rokycany-Region (West Bohemia) II. Plzeň.

VAŘEKA, P.-HOLATA, L.-PŘEROSTOVÁ, H.-ŠVEJNOHA, J., 2008: Zaniklé středověké vesnice na Blovicku (Plzeňský kraj) - Untergegangene mittelalterliche Dörfer in der Gegend um Blovice (Pilsener Land), AH 33, 85-100.

VAŘEKA, P.-HOLATA, L.-ROŽMBERSKÝ, P.-SCHEJBALOVÁ, Z., 2011: Středověké osídlení Rokycanska a problematika zaniklých vsí - Die Besiedelung der Region Rokycany im Mittelalter und die Problematik von Dorfwüstungen, AH 36, 319-342.

\section{Souhrn}

\section{Pozdně středověký hospodářský dvůr v Rovném (okres Rokycany, Plzeňský kraj)}

Rovný zřejmě vznikl v první polovině 14. století společně s dalšími vesnicemi zakládanými při sídelním postupu do Radečské vrchoviny v tomto období, kdy byla dokončena výstavba sídelní sítě na Rokycansku. Součástí vesnice se stalo sídlo drobného šlechtice, kterému náležela nevelká država tvořená vlastním Rovným a na konci 14. věku také sousedním Cetkovem (taktéž zaniklá ves). Rozdrobená držba nižší šlechty je charakteristická pro velkou část Rokycanska, stejně jako množství drobných vrchnostenských sídel, jichž je v pozdním středověku doloženo na území dnešního okresu více než padesát. K výrazné redukci osídlení došlo v průběhu 15. století, kdy zaniklo téměř $40 \%$ vsí, z nichž pouze čtvrtina byla znovu vysazena v 16 . století. Současně byla postižena také vrchnostenská sídla zahrnující dvory, tvrze i hrady, z nichž velká část byla opuštěna. Stejně jako jinde v Čechách můžeme tento proces spojovat s dopady dlouhých husitských a poděbradských válek, které zvláště těžce postihly širší Plzeňsko, ovšem v neobnovení sídel se zřejmě skládá více příčin. Archeologicky dokumentujeme u řady pustých vsí i vrchnostenských sídel na Rokycansku katastrofické požárové horizonty, které naznačují povahu zániku. Ves Rovný byla částečně obnovena v 16 . věku, kdy se stala součástí velkých 
dominií. To bylo zřejmě důvodem, proč zůstalo vrchnostenské sídlo opuštěné. K definitivnímu zpustnutí vsi došlo během třicetileté války.

Nedestruktivním výzkumem byl na lokalitě dokumentován celý sídelní komplex tvořený vsí s pravděpodobně osmi usedlostmi, tvrz, poplužní dvůr, mlýn a kaskáda rybníků ze 14. až první poloviny 15. století a podařilo se rozpoznat i sídelní fázi z mladšího novověku. Detailní průzkum (geofyzikální průzkum, vrty) a následný menší odkryv se zaměřil na vrchnostenský dvůr, což je typ usedlosti, kterému česká archeologie nevěnuje odpovídající pozornost. Dvůr o rozměrech ca $50 \times 50 \mathrm{~m}$ tvořily čtyři stavby, které zanechaly povrchově patrné pozůstatky. Jádrem dvora je velký dům pravděpodobně roubené konstrukce na kamenné podezdívce obdélného půdorysu $(9 \times 22 \mathrm{~m}) \mathrm{s}$ vyzděným plochostropým suterénem, který poskytoval rozsáhlé skladovací kapacity. Stavba mohla doplňovat obytné a zejména skladovací kapacity tvrze, jejíž částečně zděný palác měl mnohem menší rozměry a vzhledem $\mathrm{k}$ umístění na ostrůvku v rybníce nemohl být opatřen sklepem. Vedle toho však mohla sloužit ke správě malého panství nižšího šlechtice a jeho režijního hospodaření. Naproti se na severozápadní straně nacházel dvojdílný dům tvořený jizbou s kamennou pecí (ca $6 \times 6 \mathrm{~m}$ ) a připojenou komorou se zapuštěnou spodní částí (ca $4 \times 7 \mathrm{~m}$ ), který odpovídá podobě pozdně středověkých vesnických domů zjištěných v regionu. Dům byl roubené konstrukce spočívající na kamenných podezdívkách a spodní komora byla opatřrena kamennou plentou. Dvojdílný dům interpretujeme jako obydlí šafáře a jeho rodiny, která si v komorové části uchovávala vlastní zásoby. Na severovýchodní a jihozápadní straně dvora nacházíme čtvercové stavby, které považujeme za vrchnostenské sýpky. Sondáž jedné z nich potvrdila dřevěnou, zřejmě roubenou konstrukci na kamenné podezdívce. V blízkosti dvojdílného domu se nachází zahloubený objekt, který považujeme za výrobní zařízení, snad sušárnu zemědělských a zahradních produktů. Další prŕípadné stavby nelze vyloučit, zejména chybějící chlévy, jejichž identifikaci bude věnována další pozornost. Odkryv prokázal přítomnost požárového horizontu a postrádáme jakékoliv archeologicky doložené stopy pokusu o obnovu dvora. Zániku s povahou násilně „zastaveného života“ odpovídají i nálezy tvořené především keramickým inventářem a železnými artefakty. Hmotná kultura však nevykazuje žádné stopy sociální exkluzivity. Bohaté botanické makrozbytky získané flotací vzorků ze spáleništních vrstev jsou v současnosti předmětem analýzy (nálezy kostí vzhledem k půdním podmínkám zcela postrádáme). Další výzkum zahrne dokončení nedestruktivního a málo destruktivního výzkumu plochy dvora (geofyzikální průzkum, vrty, půdní analýzy).

Mgr. David Novák, Katedra archeologie Filozofické fakulty Západočeské univerzity v Plzni, Sedláčkova 15, 30614 Plzeň, Česká republika,novak@arup.cas.cz

doc. PhDr. Pavel Vařeka, Ph.D., Katedra archeologie Filozofické fakulty Západočeské univerzity v Plzni, Sedláčkova 15, 30614 Plzeň, Česká republika,vareka@kar.zcu.cz 
